\title{
Pengembangan Bahan Ajar Bahasa Arab Berbasis Pendekatan Komunikatif
}

\author{
Noza Aflisia \\ Instutut Agama Islam Negeri Curup \\ nozaaflisia@iaincurup.ac.id \\ Hazuar \\ Instutut Agama Islam Negeri Curup \\ azazwae@gmail.com
}

\begin{abstract}
This study aims to develop Arabic teaching materials with a communicative approach for MA Muhammadiyah Curup students by analyzing the needs and validation/feasibility of Arabic teaching materials with the communicative approach according to experts' assessments. Researchers develop teaching materials based on this communicative approach aimed at improving students' ability in mastering Arabic which is not only theoretical but also practical and communicative. Data collection techniques using observation, questionnaires, interviews, and documentation. Likert scale is used for questionnaires and qualitative data analysis techniques using data reduction, data display, and verification. The results showed that Arabic teaching materials that have been used are not yet relevant to the needs of students and have not maximally improved students' Arabic speaking skills. The development of Arabic language teaching materials compiled is based on the results of planning and design development with three themes namely al-Bayanaats ashSyakhshiyyah, al-Hayah Fi al-Usrah, and al-Murafiq al-Ammah Fi alMadrasah. This Arabic module has 28 pages. The average value of the validator for the initial design of this Arabic teaching material module is 22.87 with a very good category.
\end{abstract}

Keywords: Teaching material, Arabic language, communicative approach

\begin{abstract}
Abstrak
Penelitian ini bertujuan untuk mengembangkan bahan ajar Bahasa Arab dengan pendekatan komunikatif untuk siswa MA Muhammadiyah Curup dengan melakukan analisis kebutuhan dan validasi/kelayakan bahan ajar Bahasa Arab dengan pendekatan
\end{abstract}


komunikatif tersebut menurut penilaian para ahli. Peneliti mengembangkan bahan ajar berbasis pendekatan komunikatif ini bertujuan untuk meningkatkan kemampuan siswa dalam penguasaan Bahasa Arab yang tidak hanya sekedar teoritis tetapi juga praktis dan komunikatif. Teknik pengumpulan data menggunakan observasi, kuesioner, wawancara, dan dokumentasi. Skala Likert digunakan untuk angket dan teknik analisis data kualitatif menggunakan data reduction, data display, dan verification. Hasil penelitian menunjukkan bahan ajar Bahasa Arab yang telah digunakan belum relevan dengan kebutuhan siswa dan belum maksimal meningkatkan kemampuan berbicara Bahasa Arab siswa. Pengembangan bahan ajar Bahasa Arab yang disusun ini berdasarkan hasil perencanaan dan desain pengembangan dengan tiga tema yaitu al-Bayanaats asySyakbshiyyah, al-Hayah Fi al-Usrah, dan al-Murafiq al-Ammah Fi alMadrasah. Modul Bahasa Arab ini berjumlah 28 halaman. Rata-rata nilai dari validator terhadap desain awal modul bahan ajar Bahasa Arab ini yaitu 22,87 dengan kategori sangat baik.

Kata Kunci: Bahan ajar, bahasa Arab, pendekatan komunikatif

\section{Pendahuluan}

Pembelajaran bahasa Arab merupakan suatu proses memberikan ilmu dan pengetahuan baik itu yang berkenaan dengan unsur bahasa Arab maupun keterampilan berbahasa Arab kepada siswa. Dalam sebuah proses pembelajaran bahasa Arab tidak akan terlaksana tanpa ada komponen-komponen yang terlibat didalamnya, seperti guru yang berkompeten, siswa yang siap menerima ilmu pengetahuan dan materi yang akan diajarkan. Dalam memberi materi kepada siswa ada hal penting yang menjadi perhatian agar materi dapat tersampaikan dengan maksimal yaitu penerapan metode pembelajaran, penggunaan media dan evaluasi dalam pembelajaran bahasa Arab.

Bahan ajar, metode, media, dan evaluasi yang tepat akan memberi kontribusi yang besar terhadap jalannya pembelajaran. Sehingga keterampilan berbahasa Arab yang empat bisa dimiliki oleh siswa. Apalagi dewasa ini, pembelajaran bahasa Arab tidak lagi hanya sebagai alat dalam mempelajari kitabkitab klasik, namun bahasa Arab telah menjadi tujuan yaitu skill yang melekat pada seorang pembelajar bahasa Arab, khususnya kemampuan dalam berbicara bahasa Arab. Tuntutan perkembangan ilmu pengetahuan saat ini telah menjadikan bahasa Arab sebagai salah satu bahasa komunikasi dan bahasa resmi PBB. Untuk penguasaan komunikasi dalam bahasa Arab ini telah mulai diperhatikan dalam pembelajaran bahasa Arab melalui pembelajaran bahasa Arab dengan pendekatan komunikatif. 
Pendekatan komunikatif merupakan pendekatan yang memandang bahasa sebagai sesuatu yang berkenaan dengan apa yang dapat dilakukan atau ditindakkan dengan bahasa (fungsi) atau berkenaan dengan makna apa yang dapat diungkapkan melalui bahasa (nosi) tetapi bukannya berkenaan dengan tata bahasa saja. ${ }^{1}$ Dengan kata lain bahasa digunakan untuk menyapa, membujuk, menasehati, memuji dan mengungkapkan makna tertentu, tetapi bukan untuk membeberkan kategori gramatikal yang ditemukan oleh ahli bahasa. ${ }^{2}$ Oleh karena itu pendekatan ini disusun atas dasar fungsi dan kebutuhan pembelajar, dengan harapan pembelajar dapat menggunakan bahasa untuk berkomunikasi dalam situasi yang sebenarnya dan bukan komunikasi yang dibuat-buat. Pendekatan Komunikatif adalah suatu pendekatan yang prioritas utamanya adalah berbicara bahasa arab atau menggunakan bahasa Arab sebagai bahasa komunikasi dalam berinteraksi dengan yang lainnya.

Beberapa peneliti telah melakukan penelitian mengenai pendekatan komunikatif dalam pembelajaran bahasa Arab. Seperti penelitian di Pondok Pesantren Modern Gontor yang dilakukan oleh Zaid ditemukan bahwa pengajaran bahasa arab tidak hanya pandai dalam qawaid tetapi terampil dalam mengkomunikasikan bahasa Arab tersebut secara lisan maupun tulisan. Untuk menggapai hal tersebut perlu latihan secara terus-menerus. Seorang guru tidak hanya membuat muridnya menirukan, tetapi juga mampu membuat mereka berfikir dan berbicara bahasa Arab dengan berani dan percaya diri. ${ }^{3}$

Terdapat dua corak pendekatan komunikatif, yaitu yang mengutamakan aspek gramatika bersifat fungsional, dan yang mengutamakan aspek sosiolinguistik sebagai latar penggunaan bahasa. Karena tujuan yang ingin dicapai dalam pendekatan komunikatif adalah agar siswa mampu berkomunikasi dengan bahasa Arab dalam berbagai situasi sosial dan fungsional. ${ }^{4}$ Begitu juga ciri pembelajaran bahasa Arab dengan pendekatan komunikatif yang dikatakan oleh Edi yaitu memberikan perhatian sistematis terhadap aspek fungsional dan struktur bahasa. ${ }^{5}$

${ }^{1}$ Alif Cahya Setiadi, "Pengajaran Bahasa Dengan Pendekatan Komunikatif: Analisis Atas Teori Transformatif-Generatif Noam Chomsky," At-Ta'dib 4, no. 1 (27 Agustus 2016), https://doi.org/10.21111/at-tadib.v4i1.569.

2 Andi Prastowo, Panduan Kreatif Membuat Baban Ajar Inovatif (Yogyakarta: Diva Press, 2012).

3 Abdul Hafidz Zaid, "Pendekatan Komunikatif Dalam Pengajaran Bahasa Arab (Pengalaman Pondok Modern Darussalam Gontor)," At-Ta'dib 7, no. 2 (12 Desember 2012), https://doi.org/10.21111/at-tadib.v7i2.77.

4 Ahmad Muradi, "Pendekatan Komunikatif Dalam Pembelajaran Bahasa Arab," Arabiyat: Jurnal Pendidikan Bahasa Arab Dan Kebahasaaraban 1, no. 1 (1 Juli 2014): 29-48, https://doi.org/10.15408/a.v1i1.1129.

5 Relit Nur Edi, "Pendekatan Komunikatif (Al Madkhol Al-Ittisholi) Dalam Pembelajaran Bahasa Arab," Jurnal Al Bayan UIN Raden Intan 4, no. 2 (2012), https://www.neliti.com/publications/74272/pendekatan-komunikatif-al-madkhol-al-ittisholidalam-pembelajaran-bahasa-arab. 
Untuk mewujudkan pembelajaran bahasa Arab komunikatif dapat dilakukan melalui desain enam dimensi, yaitu dimensi tujuan (umum dan khusus); dimensi model silabus; dimensi jenis aktivitas pembelajaran; dimensi peranan guru; dimensi peranan peserta didik; dan dimensi peranan bahan ajar. ${ }^{6}$ Bahan ajar yang dikembangkan mengacu pada prinsip-prinsip dalam pendekatan komunikatif yang dikemas dalam tampilan berwarna. Setiap peelajaran terdiri dari hiwar, tadribat dan mulahazhah. Validasi bahan ajar dari Validator menunjukkan bahwa bahan ajar berbasis komunikatif yang dirancang sudah valid dengan beberapa perbaikan sesuai dengan catatan dan saran dari Validator. Bahan ajar berbasis komunikatif ini dapat dijadikan pedoman dalam pengembangan bahan ajar selanjutnya.

Selain uraian yang telah dijelaskan sebelumnya terdapat beberapah hal yang harus diperhatikan dalam pengajaran bahasa Arab pendekatan komunikatif menurut Noam Chomsky yaitu: Aspek kreatif pengguna bahasa, keabstrakan lambing-lambang linguistik, keuniversalan struktur dasar linguistik, dan peranan Organisasi intelek nurani (struktur dalam) di dalam proses kognitif/mental. ${ }^{8}$

Dari beberapa penelitian yang telah dilakukan terlihat bahwa penelitian yang penulis lakukan memiliki kesamaan dengan penelitian sebelumnya, yaitu meneliti atau membahas mengenai pendekatan komunikatif, namun pada penelitian ini pendekatan komunikatif yang berhubungan dengan pembelajaran Bahasa Arab di Madrasah Aliyah Muhammadiyah Curup. Selain tempat penelitian, subjek dan fokus penelitian yang akan dilakukan ini juga sangat berbeda dengan penelitian sebelumnya, yaitu peneliti meneliti tentang pengembangan bahan ajar bahasa Arab perspektif pendekatan komunikatif.

Pendekatan komunikatif dalam pembelajaran bahasa Arab adalah menjadikan kemampuan berkomunikasi atau berinteraksi dengan bahasa Arab menjadi prioritas utama dibandingkan dengan penguasaan tata bahasa. Mental yang berani dan percaya diri dalam berbahasa Arab diperlukan dalam mewujudkan pendekatan komunikatif ini. Untuk itu seyogyanya pendekatan komunikatif ini menjadi pilihan bagi pengajar dalam mengajarkan bahasa Arab sesuai dengan tingkat pendidikan mereka, baik di tingkat Madrasah Ibtidaiyah, Madrasah Tsanawiyah maupun madrasah Aliyah.

Berdasarkan observasi dan wawancara awal yang peneliti lakukan di Madrasah Aliyah Muhammadiyah Curup, peneliti mendapati banyak siswa yang

${ }^{6}$ Zulhanan Zulhanan, "Model Pembelajaran Babasa Arab Komunikatif," Jurnal Al Bayan UIN Raden Intan 6, no. 2 (2014), https://www.neliti.com/publications/73690/model-pembelajaranbahasa-arab-komunikatif.

${ }^{7}$ Nurlaila Nurlaila, "Pengembangan Bahan Ajar Babasa Arab Berbasis Komunikatif Untuke Mahasiswa Program Studi Keperawatan Stikes Purna Bhakti Husada Batusangkar," Ta'dib 14, no. 2 (28 September 2016), https://doi.org/10.31958/jt.v14i2.206.

8 Setiadi, "Pengajaran Bahasa Dengan Pendekatan Komunikatif." 
kaku dalam berkomunikasi dengan bahasa Arab, walaupun hanya bahasa Arab yang sangat sederhana. Kemudian ketika ditanyakan mengenai kaidah bahasa Arab, diantara mereka cukup paham, artinya mereka paham akan teori tapi tidak dalam praktek berbahasa Arab. Hal ini membuat peneliti tertarik untuk menelusuri lebih dalam. Temuan di lapangan didapatkan bahwa selama ini pembelajaran bahasa Arab masih cukup kaku dan pasif sehingga belum begitu maksimal dalam pemerolehan ilmu bahasa Arab dan begitu juga dalam komunikasinya. Pada saat ini siswa membutuhkan suatu inovasi dalam pembelajaran bahasa Arab, sehingga siswa bisa lebih tertarik dan termotivasi untuk belajar bahasa Arab. Salah satu inovasi yang ingin peneliti berikan adalah melalui pengembangan bahan ajar bahasa Arab. Peneliti akan mengembangkan bahan Ajar yang sesuai dengan pendekatan komunikatif. Pengembangan bahan ajar bahasa Arab berbasis pendekatan komunikatif ini bertujuan untuk meningkatkan kemampuan siswa dalam penguasaan bahasa Arab yang tidak hanya sekedar teori qawaid tetapi juga mampu berkomunikasi dengan menggunakan bahasa Arab tersebut.

Penelitian ini bertujuan menganalisis kebutuhan guru dan siswa MA Muhammadiyah Curup terhadap bahan ajar bahasa Arab dengan pendekatan komunikatif, mengembangkan desain ajar bahasa Arab dengan pendekatan komunikatif untuk siswa MA Muhammadiyah Curup, dan menganalisis validasi/kelayakan bahan ajar bahasa Arab dengan pendekatan komunikatif menurut penilaian para ahli. Dengan adanya penelitian ini diharapkan dapat memberi inovasi dalam pembelajaran bahasa Arab melalui produk bahan ajar Bahasa Arab Berbasis Pendekatan Komunikatif di MA Muhammadiyah Curup yang dihasilkan.

Jenis penelitian ini adalah penelitian dan pengembangan. Penelitian dan pengembangan adalah metode penelitian yang digunakan untuk menghasilkan produk tertentu, dan menguji keefektifan produk tersebut. ${ }^{9}$ Prosedur penelitian dan pengembangan yang dilakukan adalah mengikuti tahapan yang dikemukan oleh Borg dan Gall dalam Setyowati yaitu sepuluh langkah prosedur penelitian dan pengembangan. ${ }^{10}$ Dalam penelitian ini, peneliti mengadaptasi prosedur tersebut dengan pembatasan yaitu hanya sampai pada langkah ke 5. Adapun pembatasan langkah-langkah tersebut sebagai berikut:

1. Penelitian dan Pengumpulan Informasi Awal

Pada tahapan awal ini peneliti melakukan identifikasi masalah yang bertujuan untuk memperoleh informasi mengenai permasalahan yang ditemui dalam proses belajar bahasa Arab di Madrasah, analisis persepsi guru dan siswa terhadap bahan ajar bahasa Arab yang selama ini digunakan bertujuan untuk 2012).

${ }^{9}$ Sugiyono, "Metode Penelitian Kuantitatif Kualitatif dan R\&D" (Bandung: Alfabeta,

${ }^{10}$ Setyowati, Metode Penelitian Pendidikan dan Pengembangan (Jakarta: Kencana, 2010). 
mengetahui mengenai kebermanfaatan dan efektivitas bahan ajar yang digunakan, dan analisis kebutuhan guru dan siswa terhadap bahan Ajar bahasa Arab berbasis pendekatan komunikatif.

\section{Perencanaan}

Adapun kegiatan yang dilakukan pada perencanaan ini yaitu merencanaan draft awal yang selanjutnya dibahas bersama para praktisi dan ahli. Selanjutnya melakukan penetapan tujuan pembelajaran. Perencanaan desain awal bahan ajar dibuat berdasarkan spesifikasi yang diperoleh melalui analisis kebutuhan, wawancara, observasi, dan angket yang diberikan kepada guru dan siswa.

3. Pengembangan Format Produk Awal

Pada tahapan ketiga ini dilakukan penyusunan desain awal produkberdasarkan hasil perencanaan. Produk bahan ajar bahasa Arab yang akan dihasilkan dalam penelitian dan pengembangan ini yaitu bahan ajar berupa modul dengan spesifikasi berdasarkan hasil analisis kebutuhan yang sudah dibuat perencanaannya.

4. Uji Coba Awal

Uji coba awal yaitu validasi ahli dengan penilaian terhadap content dan designproduk awal modul yang disusun secara rasional sudah tepat atau belum. Dikatakan rasional karena validasi masih bersifat penilaian berdasarkan pemikiran rasional, belum dari fakta lapangan. Validasi ahli dilakukan oleh dosen ahli materi, ahli penyajian, serta ahli bahasa untuk mendapatkan masukan mengenai produk awal modul. Hasil validasi ahli dimanfaatkan untuk memperbaiki desain produk awal menjadi lebih baik.

Untuk mengumpulkan data dilakukan dengan menggunakan observasi untuk memperoleh data kondisi obyektif proses pembelajaran bahasa Arab di MA Muhammadiyah Curup, kuesioner digunakan untuk memperoleh data analisis kebutuhan bahan ajar bahasa Arab dengan pendekatan komunikatif, kondisi obyektif, analisis RPP dan kelayakan bahan ajar, wawancara untuk mengumpulkan data dengan mengemukakan pertanyaan secara langsung kepada guru bahasa Arab dan siswa guna memperoleh data mengenai karakteristiksiswa, kurikulum yang digunakan, bahan ajar yang pernah digunakan dalam pembelajaran bahasa Arab di MA Muhammadiyah Curup, dan dokumentasi untuk mendapatkan data terkait objek penelitian dan kegiatan-kegiatan yang mendukung dalam proses pembelajaran bahasa Arab, baik itu tujuan, materi, metode, media, dan evaluasi.

Teknik analisis dan pengolahan data yang digunakan dalam penelitian dan pengembangan ini untuk data angket kebutuhan pengembangan bahan ajar Bahasa Arab menggunakan analisis kualitatif dan analisis kuantitatif. Angket 
tertutup menggunakan Skala Likert, Data angket hasil analisis kebutuhan dianalisis dengan menggunakan skala pengukuran rating scale. Sedangkan teknik analisis data wawancara, observasi, dan dokumentasi melalui data reduction, data display, dan verification.

\section{Hasil dan Pembahasan}

\section{Penelitian dan Pengumpulan Informasi Awal}

Penelitian dan pengumpulan informasi awal yaitu berupa identifikasi masalah dan analisis kebutuhan terhadap bahan ajar Bahasa Arab dengan pendekatan komunikatif untuk MA Muhammadiyah Curup.Tahapan awal ini dilakukan untuk mendapatkan informasi mengenai respon guru dan siswa terhadap bahan ajar Bahasa Arab yang telah digunakan selama ini dan kebutuhan mereka terhadap bahan ajar Bahasa Arab Berbasis Pendekatan Komunikatif. Untuk mengumpulkan informasi awal peneliti lakukan dengan menggunakan observasi, wawancara, studi literatur atau dokumentasi, dan angket.

Observasi dan wawancara dilakukan dalam mendapatkan informasi mengenai proses pembelajaran Bahasa Arab dan bahan ajar yang digunakan. Studi literatur atau dokumentasi dilakukan terhadap bahan ajar Bahasa Arab yang telah digunakan selama ini. Sedangkan angket peneliti gunakan untuk memperoleh masukan dan rekomendasi mengenai pembelajaran Bahasa Arab yang telah dilakukan dan bahan ajar Bahasa Arab yang akan dikembangkan. Adapun penjelasan masing-masing pengumpulan informasi tersebut adalah sebagai berikut:

1. Hasil Observasi, Dokumentasi, dan Wawancara

Survei dan dokumentasi dilakukan terhadap pembelajaran bahasa Arab berbasis Pendekatan Komunikatif dan bahan ajar Bahasa Arab yang digunakan di MA Muhammadiyah Curup. Wawancara dilakukan dengan guru Bahasa Arab MA Muhammadiyah Curup. Kegiatan survei dan dokumentasi dilakukan pada tanggal Tanggal 10 Juli 2019 dan wawancara pada tanggan 16 Juli 2019 dan 17 Juli 2019.

Berdasarkan hasil survei dan wawancara dengan guru Bahasa Arab MA Muhammadiyah Curup mengenai pembelajaran Bahasa Arab didapatkan informasi bahwa belum ada bahan ajar Bahasa Arab yang menekankan pada penguasaan kemampuan komunikasi bahasa Arab secara aktif. Buku paket yang digunakan dalam proses pembelajaran Bahasa Arab belum seutuhnya mampu mengembangkan kemampuan berbicara siswa dengan Bahasa Arab seperti yang diharapkan oleh pembelajaran berbasis pendekatan komunikatif. Selain itu, dalam buku ajar Bahasa Arab yang digunakan memiliki desain yang sama antara buku ajar Bahasa Arab yang satu dengan buku ajar Bahasa Arab yang lainnya. Buku ajar Bahasa Arab yang selama ini digunakan dalam proses pembelajaran 
memuat materi dengan sistem terpadu antara maharah istima', maharah kalam, maharah qiroah, dan maharah kitabah. Hal ini berdampak pada hasil yang diperoleh siswa yaitu tidak menguasai secara mendalam pada aspek maharah tersebut. Siswa memahami sedikit pada masing-masing maharah. Sedangkan modul yang dihasilkan ini akan fokus pada maharah kalam.

Berdasarkan data awal hasil survei, dokumentasi, dan wawancara disimpulkan bahwa 1) belum ada bahan ajar yang sesuai untuk meningkatkan maharah kalam, 2) Bahan ajar digunakan dalam pembelajaran Bahasa Arab ditulis dengan sistem terpadu yaitu memuat seluruh maharah, 3) bahan ajar yang digunakan dalam pembelajaran Bahasa Arab selama ini masih minim latihan atau tugas yang menekankan pada kemampuan berbicara bahasa Arab. Oleh karena itu, perlu disusun bahan ajar Bahasa Arab berbasis pendekatan komunikatif.

2. Hasil Angket Persepsi Guru dan Siswa tentang Bahan Ajar Bahasa Arab yang Selama Ini Digunakan

Angket persepsi guru dan siswa dilakukan pada Tanggal 25 Juli 2019 s.d. 26 Juli 2019. Angket persepsi guru dan siswa ini digunakan dengan tujuan untuk mengetahui persepsi guru dan siswa MA Muhammadiyah Curup terhadap bahan ajar Bahasa Arab yang digunakan selama ini. Pengumpulan data persepsi guru dan siswa telah. Muatan angket persepsi guru dan siswa yaitu:

a. 20 (dua puluh) pernyataan

b. 1 (satu) saran

c. Pilihan jawaban untuk pernyataan, yaitu:

1) Tidak Benar/Tidak Sesuai/Tidak Pernah

2) Kurang Benar/Kurang Sesuai/Jarang

3) Benar/Sesuai/Pernah

4) Sangat Benar/Sangat Sesuai/Selalu

Angket persepsi guru diberikan kepada guru Bahasa Arab MA Muhammadiyah yang berjumlah 2 (dua) guru. Data rekapitulasi hasil angket persepsi guru terhadap bahan ajar Bahasa Arab yang digunakan selama ini dalam proses pembelajaran diketahui sebagai berikut:

a. Total yang memilih skala 4 yaitu 0 atau dapat dikatakan $0 \%$ guru yang menyatakan sangat sesuai terhadap bahan Bahasa Arab yang digunakan selama ini.

b. Total yang memilih skala 3 yaitu 7 atau dapat dikatakan $18 \%$ guru yang menyatakan sesuai terhadap bahan Bahasa Arab yang digunakan selama ini.

c. Total yang memilih skala 2 yaitu 16, atau dapat dikatakan $40 \%$ guru yang menyatakan kurang sesuai terhadap bahan Bahasa Arab yang digunakan selama ini. 
d. Total yang menjawab skala 1 yaitu 17 atau dapat dikatakan $42 \%$ guru yang menyatakan tidak sesuai terhadap bahan Bahasa Arab yang digunakan selama ini.

e. Jadi, $82 \%$ guru menyatakan bahwa bahan ajar Bahasa Arab yang digunakan selama ini kurang sesuai dan tidak sesuai.

Data hasil persepsi guru terhadap bahan ajar Bahasa Arab yang digunakan selama ini dapat dilihat pada grafik berikut.

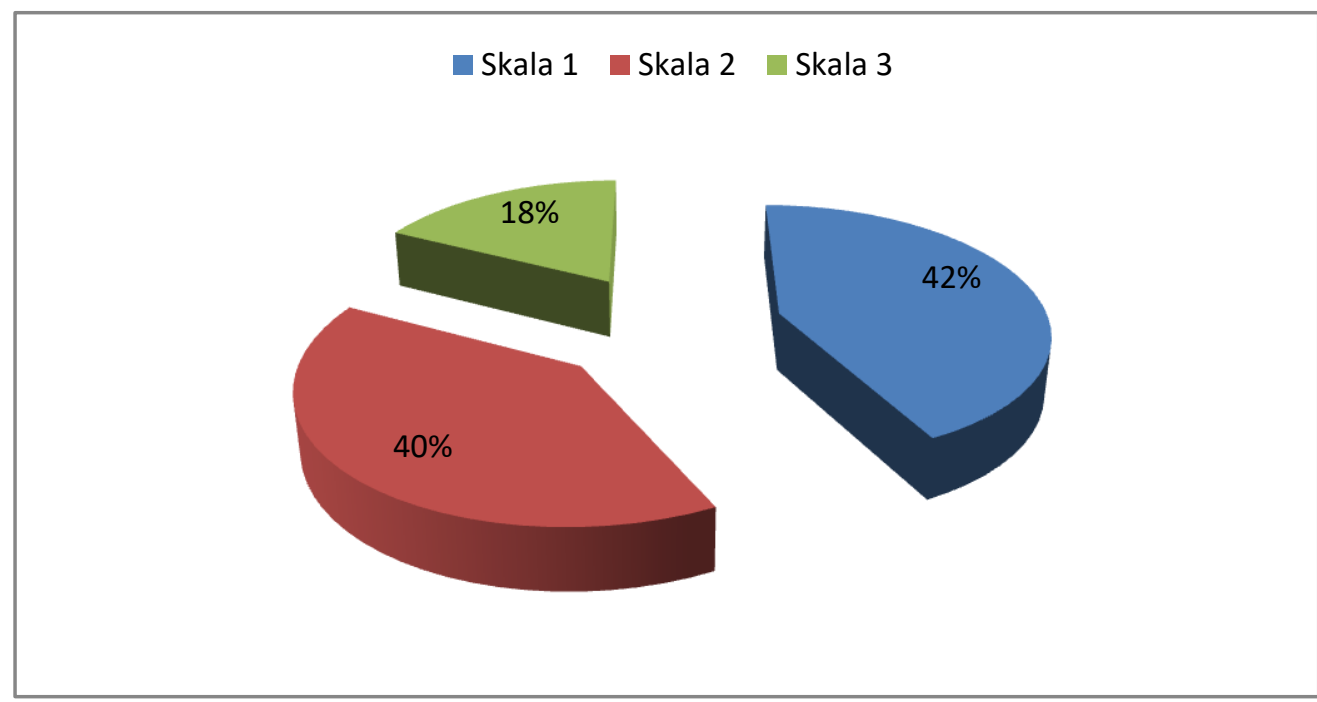

\section{Grafik 1}

\section{Persepsi Guru Mata Pelajaran Bahasa Arab Terhadap Bahan Ajar Bahasa Arab yang Digunakan Selama Ini}

Sedangkan data rekapitulasi hasil angket persepsi siswa terhadap bahan ajar Bahasa Arab yang digunakan selama ini dalam proses pembelajaran diketahui sebagai berikut:

a. Total yang memilih skala 4 yaitu 0 atau dapat dikatakan $0 \%$ siswa yang menyatakan sangat sesuai terhadap bahan Bahasa Arab yang digunakan selama ini.

b. Total yang memilih skala 3 yaitu 30 atau dapat dikatakan 5\% siswa yang menyatakan sesuai terhadap bahan Bahasa Arab yang digunakan selama ini.

c. Total yang memilih skala 2 yaitu 193, atau dapat dikatakan $29 \%$ siswa yang menyatakan kurang sesuai terhadapbahan Bahasa Arab yang digunakan selama ini.

d. Total yang menjawab skala 1 yaitu 437 atau dapat dikatakan 66\% siswa yang menyatakan tidak sesuai terhadap bahan Bahasa Arab yang digunakan selama ini. 
Jadi, 95\% siswa menyatakan bahwa bahan ajar Bahasa Arab yang digunakan selama ini kurang sesuai dan tidak sesuai. Data hasil persepsi siswa terhadap bahan ajar Bahasa Arab yang digunakan selama ini dapat dilihat pada grafik berikut.

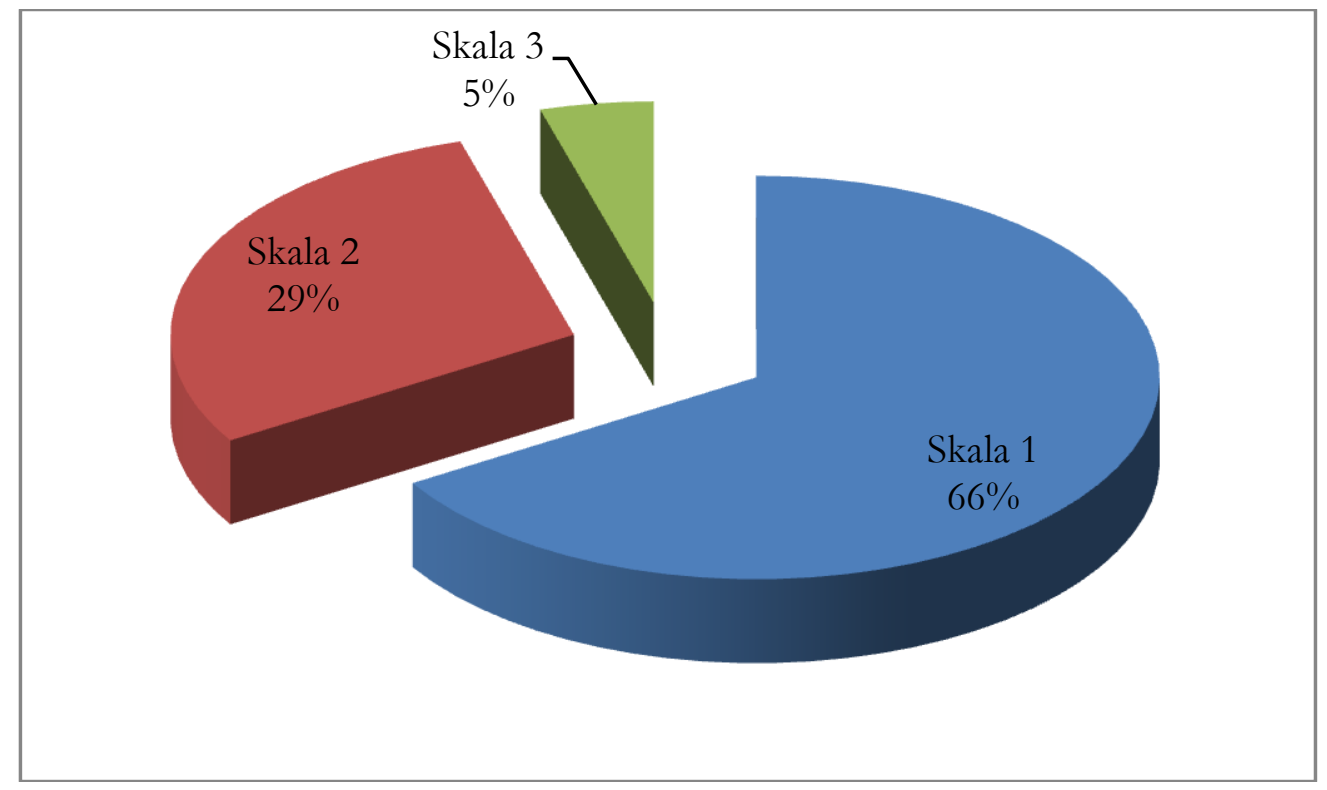

\section{Grafik 2}

\section{Persepsi Siswa terhadap Bahan Ajar Bahasa Arab} yang Digunakan Selama Ini

Berdasarkan rekapitulasi hasil angket persepsi guru dan siswa terhadap bahan ajar Bahasa Arab yang digunakan selama ini dalam proses pembelajaran menunjukkan sebagai berikut:

a. Tidak ada guru dan siswa menyatakan sangat sesuai terhadap bahan ajar Bahasa Arab yang digunakan selama ini.

b. $18 \%$ guru dan $5 \%$ siswa menyatakan sesuai terhadap bahan ajar Bahasa Arab yang digunakan selama ini.

c. $40 \%$ guru dan $29 \%$ siswa menyatakan kurang sesuai terhadap bahan ajar Bahasa Arab yang digunakan selama ini.

d. $42 \%$ guru dan $66 \%$ siswa menyatakan tidak sesuai terhadap bahan ajar Bahasa Arab yang digunakan selama ini.

Secara keseluruhan dapat disimpulkan bahwa $82 \%$ guru dan 95\% siswa menyatakan kurang sesuai dan tidak sesuai bahan ajar Bahasa Arab yang digunakan selama ini. 
3. Hasil Angket Kebutuhan Guru dan Siswa Terhadap Bahan Ajar Bahasa Arab Berbasis Pendekatan Komunikatif yang Akan Dikembangkan

Angket kebutuhan guru dan siswa dilakukan untuk memperoleh informasi tentang kebutuhan guru dan siswa terhadap bahan ajar Bahasa Arab yang akan dikembangkan. Angket kebutuhan kepada guru telah disebarkan kepada guru pengampu mata pelajaran Bahasa Arab di MA Muhammadiyah Curup. Angket kebutuhan guru dan siswa memuat 19 pernyataan dan 1 saran. Pernyataan disertai 4 pilihan jawaban, yaitu: 1. Tidak Dibutuhkan/Tidak Perlu, 2. Kurang Dibutuhkan/Kurang Perlu, 3. Dibutuhkan/Perlu, dan 4. Sangat Dibutuhkan/Sangat Perlu. Data rekapitulasi hasil angket kebutuhan guru terhadap bahan ajar Bahasa Arab berbasis pendekatan komunikatif diketahui sebagai berikut:

a. Total yang memilih skala 4 yaitu 38 atau dapat dikatakan 95\% guru yang menyatakan sangat dibutuhkan bahan ajar Bahasa Arab berbasis pendekatan komunikatif.

b. Total yang memilih skala 3 yaitu 2 atau dapat dikatakan 5\% guru yang menyatakan dibutuhkan bahan ajar Bahasa Arab berbasis pendekatan komunikatif.

c. Total yang memilih skala 2 yaitu 0 atau dapat dikatakan $0 \%$ guru yang menyatakan kurang dibutuhkan bahan ajar Bahasa Arab berbasis pendekatan komunikatif.

d. Total yang memilih skala 1 yaitu 0 atau dapat dikatakan $0 \%$ guru yang menyatakan tidak dibutuhkan bahan ajar Bahasa Arab berbasis pendekatan komunikatif.

Data hasil kebutuhan guru terhadap bahan ajar Bahasa Arab berbasis pendekatan komunikatif dapat dilihat pada grafik berikut.

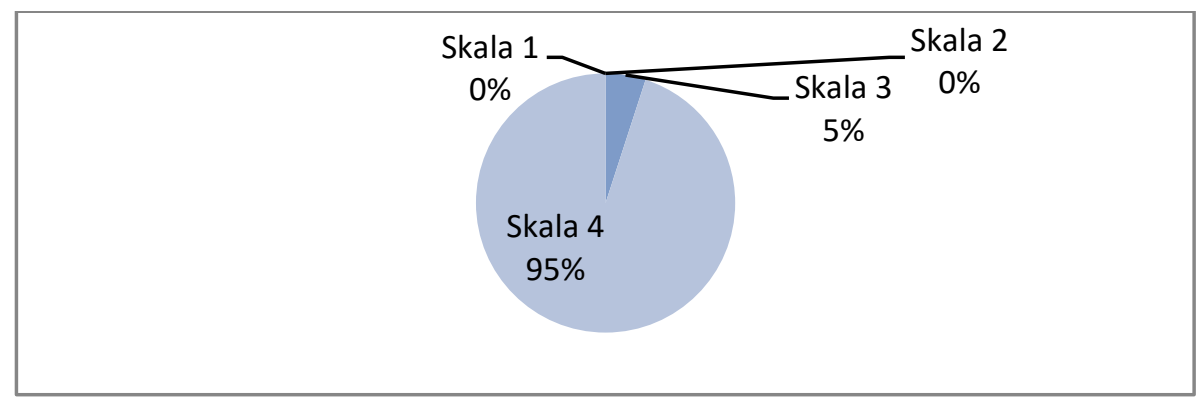

Grafik 3

Hasil Angket Kebutuhan Guru Mata Pelajaran Bahasa Arab terhadap Bahan Ajar Bahasa Arab Berbasis Pendekatan Komunikatif

Adapun untuk rekapitulasi hasil angket kebutuhansiswa terhadap bahan ajar Bahasa Arab berbasis pendekatan komunikatif diketahui sebagai berikut: 
a. Total yang memilih skala 4 yaitu 531 atau dapat dikatakan $85 \%$ siswa yang menyatakan sangat dibutuhkan bahan ajar Bahasa Arab berbasis pendekatan komunikatif.

b. Total yang memilih skala 3 yaitu 96 atau dapat dikatakan 15\% siswa yang menyatakan dibutuhkan bahan ajar Bahasa Arab berbasis pendekatankomunikatif.

c. Total yang memilih skala 2 yaitu 0 atau dapat dikatakan $0 \%$ siswa yang menyatakan kurang dibutuhkan bahan ajar Bahasa Arab berbasis pendekatan komunikatif.

d. Total yang memilih skala 1 yaitu 0 atau dapat dikatakan $0 \%$ siswa yang menyatakan tidak dibutuhkan bahan ajar Bahasa Arab berbasis pendekatan komunikatif.

Data hasil kebutuhan siswa terhadap bahan ajar Bahasa Arab berbasis pendekatan komunikatif dapat dilihat pada grafik berikut.

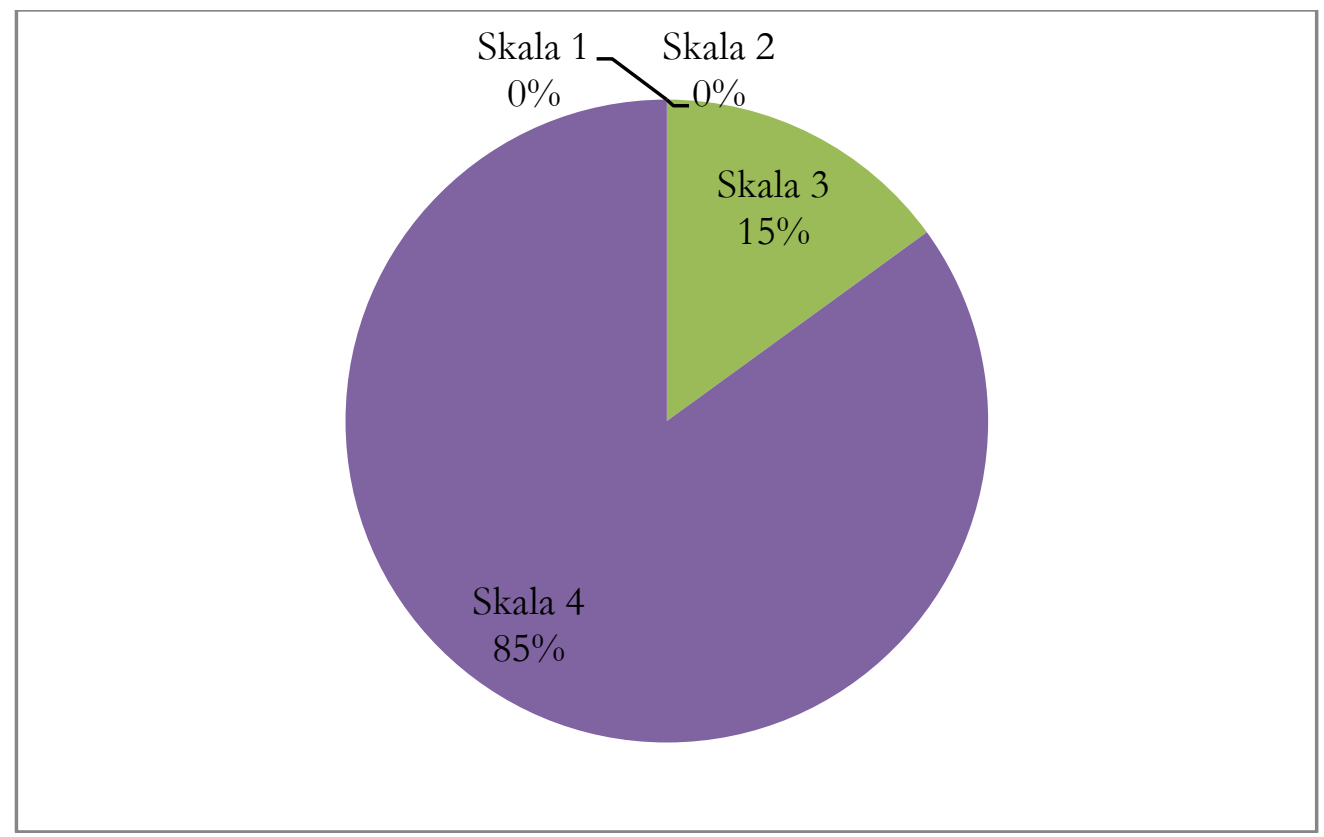

\section{Grafik 4}

Hasil Angket Kebutuhan siswa MA Muhammadiyah TerhadapBahan Ajar Bahasa Arab Berbasis Pendekatan Komunikatif

Berdasarkan rekapitulasi hasil angket kebutuhanguru dan siswa MA Muhammadiyah Curup terhadap bahan ajar Bahasa Arab Berbasis Pendekatan Komunikatif yang akan dikembangkan dalam proses pembelajaran Bahasa Arab menunjukkan sebagai berikut: 
a. 95\% guru dan $85 \%$ siswa MA Muhammadiyah Curup menyatakan bahwa sangat dibutuhkan bahan ajar Bahasa Arab Berbasis Pendekatan Komunikatif untuk siswa MA Muhammadiyah Curup.

b. 5\% guru dan 15\% siswa MA Muhammadiyah Curup menyatakan bahwa dibutuhkan bahan ajar Bahasa Arab Berbasis Pendekatan Komunikatif untuk siswa MA Muhammadiyah Curup.

c. $0 \%$ guru dan $0 \%$ siswa MA Muhammadiyah Curup menyatakan bahwa kurang dibutuhkan dan tidak dibutuhkan bahan ajar Bahasa Arab Berbasis Pendekatan Komunikatif untuk siswa MA Muhammadiyah Curup.

Secara keseluruhan dapat disimpulkan bahwa seluruh guru dan siswa menyatakan sangat dibutuhkan dan dibutuhkan bahan ajar Bahasa Arab berbasis pendekatan komunikatif.

\section{Hasil Perencanaan Desain Pengembangan Bahan Ajar Bahasa Arab Berbasis Pendekatan Komunikatif untuk Siswa Madrasah Aliyah Muhammadiyah Curup}

Hasil perencanaan desain awal pengembangan bahan ajar Bahasa Arab Berbasis Pendekatan Komunikatif untuk Siswa MA Muhammadiyah Curup adalah disusun sesuai dengan spesifikasi yang didapatkan dari analisis kebutuhan guru dan siswa.Berdasarkan analisis kebutuhan bahan ajar Bahasa Arab Berbasis Pendekatan Komunikatif, disusun perencanaan pengembangan bahan ajar Bahasa Arab Berbasis Pendekatan Komunikatif yang diharapkan dapat membantu meningkatkan kompetensi siswa dalam berbicara dengan bahasa Arab.

Adapun rancangan bahan ajar Bahasa Arab Berbasis Pendekatan Komunikatif dalam bentuk modul untuk siswa MA Muhmmadiyah Curup adalah sebagai berikut :

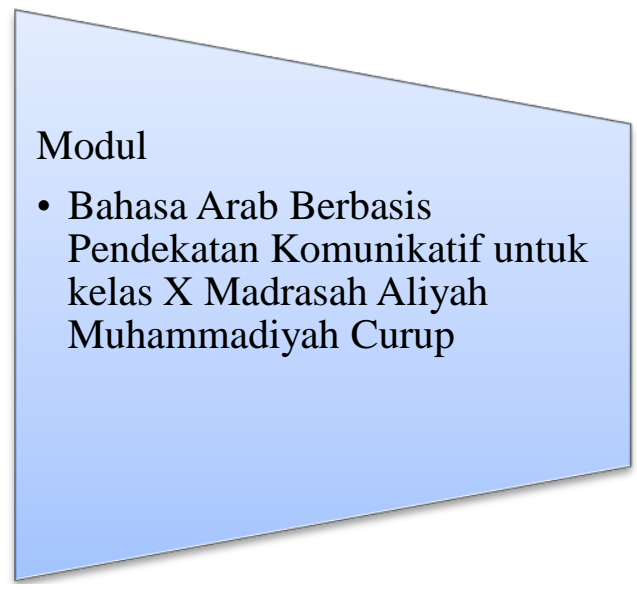

\section{Spesifikasi Produk}

- Pendahuluan (Kata Pengantar, Daftar Isi)

- Materi (Indikator Pembelajaran, Mufradat Jadidah, Hiwar, Kaidah, Tadriba ts, Mahfuzhat)

- Penutup (Daftar Mufradat)

\section{Bagan 1}

Perencanaan Desain Bahan Ajar Bahasa Arab dalam Bentuk Modul 
Penyusunan modul ini dengan tidak mengabaikan karakteristik modul yang baik yaitu Self instruction, Self Contained, Stand Alone, adaptif, dan User Friendly.11 Sebagaimana yang diungkapkan oleh Sukiminiandari bahwa penggunaan modul di dalam kegiatan belajar mengajar tidak hanya memandang aktivitas guru semata, melainkan juga melibatkan siswa secara aktif dalam belajar. Dengan menggunakan modul juga menciptakan proses belajar yang mandiri. ${ }^{12}$

\section{Hasil Pengembangan Format Produk Awal Bahan Ajar Bahasa Arab dengan Pendekatan Komunikatif untuk Siswa MA Muhammadiyah Curup}

Pengembangan format produk awal bahan ajar Bahasa Arab berbasis pendekatan komunikatif berdasarkan pada :

a. Hasil Perencanaan

Dalam mengembangkan desain awal bahan ajar Bahasa Arab berbasis pendekatan komunikatif dilakukan dengan mengkaji bahan ajar Bahasa Arab yang digunakan di MA Muhammadiyah Curup. Selain itu juga dilakukan melalui observasi dan wawancara dengan guru dan siswa mengenai bahan ajar Bahasa Arab yang digunakan selama ini. Untuk menghasilkan bahan ajar berupa modul yang berkualitas, peneliti lakukan dengan mempelajari dan memahami teknik penyusunan bahan ajar berbentuk modul, mengkaji beberapa literatur, dan menganalisis silabus dan Rencana Pelaksanaan Pembelajaran (RPP) mata pelajaran Bahasa Arab.

b. Analisis Tujuan Pembelajaran

Menyusun perangkat pembelajaran sesuai kompetensi siswa dan indikator yang akan dicapai. Berdasarkan perangkat pembelajaran yang sudah disusun, peneliti menyusun materi modul dan evaluasi terkait materi.

c. Pengembangan Materi Pembelajaran

Bahan ajar seyogyanya unik dan spesifik. Unik maksudnya bahan ajar cuma bisa dipakai oleh pembelajar tertentu di dalam proses pembelajaran tertentu pula. Spesifik maksudnya materi dari bahan ajar tersebut didesain guna meraih tujuan tertentu dan sistematika dalam penyampaiannya pun disesuaikan

${ }^{11}$ Daryanto Daryanto, Menyusun Modul (Bahan Ajar Untuk Persiapan Guru Dalam Mengajar (Yogyakarta: Gava Media, 2013).

${ }^{12}$ Yunieka Putri Sukiminiandari, Agus Setyo Budi, Dan Yetti Supriyati, "Pengembangan Modul Pembelajaran Fisika Denganpendekatan Saintifik," Prosiding Seminar Nasional Fisika (EJournal) 4 (30 Oktober 2015): Snf2015-Ii-161-64. 
dengan karakteristik mata pelajaran dan karakteristik pembelajar yang memakainya. ${ }^{13}$ Adapun pengembangan materi yang disusun meliputi:

1) al-Bayanats asy-Syakhshiyyah

2) al-Hayah Fi al-Usrah

3) al-Murafiq al-'Ammah Fi al-Madrasah

Materi yang dipaparkan adalah dalam bentuk hiwar atau percakapan sesuai dengan kemampuan yang harus dikuasai dalam Bahasa Arab berbasis komunikatif ini. Selain materi, di dalam modul juga dimuat kaidah yang mendukung siswa dalam berbicara Bahasa Arab. Supaya biwar dan qa'idah dapat dipraktekkan dengan baik, maka dalam modul ini dimuat juga tadribat atau latihan yang semuanya bertujuan meningkatkan kemampuan berbicara Bahasa Arab siswa. Kemudian guna untuk memotivasi siswa dalam belajar, dalam modul ini diberi muatan mabfurhat yaitu kata mutiara penyemangat siswa dalam belajar dan menuntut ilmu.

Hasil desain awal pengembangan bahan ajar Bahasa Arab berbasis pendekatan komunikatif dalam bentuk modul secara keseluruhan terdiri dari 28 halaman. Isi bahan ajar Bahasa Arab tersebut adalah sebagai berikut:

a. Pendahuluan

1) Kata Pengantar

2) Daftar Isi

b. Kegiatan Belajar

1) Indikator Pembelajaran

2) al-Mufradat al-Jadidah

3) Hiwar

4) Qa'idah

5) Tadribat

6) Mahfurbat

c. Penutup (daftar mufradat)

Bagian pertama yaitu Pendahuluan terdiri dari Cover (2 halaman), Kata Pengantar (1 halaman) dan Daftar Isi (1 halaman). Bagian kedua yaitu Kegiatan Belajar terdiri dari indikator pembelajaran, mufradat jadidah, qa’idah, tadribat, dan mahfurbat. Bagian ketiga yaitu Penutup berisi daftar mufradat. Tidak hanya materi, modul Bahasa Arab juga dilengkapi dengan gambar-gambar sesuai dengan tema yang dipelajari. Penyajian materi diberi variasi warna agar lebih menarik.Untuk Bahasa Arab menggunakan font Sakkal Majalla dengan ukuran 24. Sedangkan Bahasa Indonesia menggunakan font Berlin Sans FB ukuran 11

${ }^{13}$ Zakiyah Arifa dan Dewi Chamidah, "Pengembangan Bahan Ajar Qawaid Bahasa Arab Berbasis Mind Map Untuk Tingkat Perguruan Tinggi," El-Qudwab: Jurnal Penelitian Integrasi Sains Dan Islam 4 (2011), http:// ejournal.uin-malang.ac.id/index.php/lemlit/article/view/1947. 
pada kegiatan belajar dan menggunakan font Garamond ukuran 14 pada kata pengantar.

Hasil desain awal pengembangan produk bahan ajar modul Bahasa Arab berbasis pendekatan komunikatif ini kemudian divalidasi oleh ahli yang berjumlah dua orang. Adapun aspek yang divalidasi adalah aspek kelayakan materi/isi, kelayakan bahasa, kelayakan penyajian, dan kelayakan grafik. Dilakukan validasi pada aspek tersebut untuk mengetahui apakah desain awal modul Bahasa Arab berbasis pendekatan komunikatif yang dihasilkan layak untuk digunakan/diujicobakan untuk MA Muhammadiyah Curup atau tidak.

\section{Hasil Uji Coba Awal (Validasi Ahli) terhadap Pengembangan Bahan Ajar Bahasa Arab Berbasis Pendekatan Komunikatif untuk Siswa Madrasah Aliyah Muhammadiyah Curup}

Validasi ahli terhadap desain awal pengembangan bahan ajar Bahasa Arab berbasis pendekatan komunikatif untuk siswa MA Muhammadiyah Curup dilaksanakan dilakukan setelah pengembangan format produk awal modul diperoleh. Validasi desain dalam penelitian ini dilakukan oleh ahli isi/materi, ahli bahasa, ahli penyajian, dan ahli kegrafikan. Selain ahli melakukan validasi, ia juga memberikan saran mengenai kelebihan dan kekurangan desain produk awal bahan ajar dalam bentuk modul yang telah dihasilkan. Hasil yang didapatkan dari ahli, baik berupa validasi kelayakan maupun saran mengenai produk bahan ajar yang telah dihasilkan, digunakan untuk memperbaiki desain produk awal supaya menjadi lebih baik dari sebelumnya.

Validasi telah dilaksanakan pada tanggal 7-8 November 2019. Muatan Instrumen validasi yang dibagikan kepada validator adalah: Pertama, berisi tabel penilaian dengan skala 1-5. Dan Kedua, mengenai saran untuk untuk pengembangan bahan ajar modul Bahasa Arab berbasis pendekatan komunikatif yang diberikan oleh validator, serta simpulan hasil validasi.

Validasi ini bertujuan untuk mengetahui kekurangan/kekeliruan serta kelebihan dari desain awal bahan ajar Bahasa Arab yang dihasilkan. Tanggapan dan Saran yang diberikan oleh validator menjadi acuan untuk perbaikan dalam pengembangan produk bahan ajar Bahasa Arab berbasis pendekatan komunikatif.

Catatan penting yang diberikan validator 1 terhadap bahan ajar Bahasa Arab berbasis pendekatan komunikatif untuk MA Muhammadiyah Curup yang telah dikembangkan adalah: Modul pembelajaran Bahasa Arab ini telah baik, namun akan lebih baik bila ada beberapa bentuk kalimat yang muannas (dengan menggunakan dhomir Muannas) sehingga ada keseimbangan informasi penggunaan dhomir antara muzakkar dan muannas. Kemudian mengenai urutan materi ada baiknya dimulai dari yang terdekat dengan siswa, yaitu dirinya, keluarga, dan sekolah. Kesimpulan yang diberikan oleh validator 1 adalah bahan 
ajar modul Bahasa Arab berbasis pendekatan komunikatif ini dinyatakan layak untuk diujicobakan dengan revisi sesuai saran.

Catatan penting yang diberikan validator 2 terhadap bahan ajar Bahasa Arab berbasis pendekatan komunikatif untuk MA Muhammadiyah Curup yang telah dikembangkan adalah: Secara umum modul layak digunakan dan diujicobakan dengan memeperhatikan kembali salah satu indikator kalam yaitu penguasaan kosakata yang mumpuni. Modul ini masih perlu ditambah muatan kosakata dan di bagian akhir modul lampirkan daftar kosakata sehingga siswa dapat merujuk beberapa kosakata di bagian akhir.Selain itu perlu tambahkan bentuk muhadatsah yang lebih beragam. Di dalam modul ini bentuk percakapan masih sedikit dan muatan materi di dalam percakapan hendaknya diperkaya lagi. Selanjutnya untuk kaidah, hendaknya ditambahkan di dalam modul ini. Sehingga terlihat setiap muhadatsah dimuati oleh kaidah. Jadi siswa paham ta'bir syafabiy dan ta'bir tabriri yang digunakan. Adapun mengenai bahasa yang digunakan dalam modul ini cukup sederhana, mudah dimengerti, efektif, efesien, dan jelas. Kesimpulan yang diberikan oleh validator 2 adalah bahan ajar modul Bahasa Arab berbasis pendekatan komunikatif ini dinyatakan layak untuk diujicobakan dengan revisi sesuai saran. Adapun rekapitulasi seluruh nilai yang diberikan oleh validator adalah sebagai berikut:

\section{Tabel}

Rekapitulasi Nilai Desain Awal Modul Bahan Ajar Bahasa Arab Berbasis Pendekatan Komunikatif untuk MA Muhammadiyah Curup

\begin{tabular}{|c|c|c|c|c|}
\hline No & Aspek Penilaian & Validator 1 & Validator 2 & Rata-rata \\
\hline 1 & Kelayakan isi/mater & 24 & 22 & 23 \\
\hline 2 & Kelayakan bahasa & 24 & 21 & 22,5 \\
\hline 3 & Kelayakan penyajian & 24 & 21 & 22,5 \\
\hline 4 & $\begin{array}{l}\text { Kelayakan } \\
\text { kegrafikan }\end{array}$ & 24 & 23 & 23,5 \\
\hline \multicolumn{2}{|c|}{ Jumlah } & 96 & 87 & 91,5 \\
\hline \multicolumn{2}{|c|}{ Rata-rata } & 24 & 21,75 & 22,87 \\
\hline \multicolumn{2}{|c|}{ Nilai } & \multicolumn{2}{|c|}{ Sangat Baik } & \\
\hline
\end{tabular}

Rata-rata nilai dari validator terhadap desain awal modul bahan ajar Bahasa Arab berbasis pendekatan komunikatif untuk siswa MA Muhammadiyah yaitu 22,87 dengan kategori sangat baik. Secara umum hasil validasi para ahli menyatakan bahwa desain awal bahan ajar Bahasa Arab berbasis pendekatan komunikatif yang telah dikembangkan ini dapat ditindaklanjuti untuk uji coba. Kedua validator memberikan kesimpulan bahwa bahan ajar Bahasa Arab berbasis pendekatan komunikatif ini layak untuk diujicobakan dengan revisi sesuai saran. Semua catatan dan saran yang telah diberikan oleh para validator 
tersebut (instrumen terlampir), diperhatikan dan ditindaklanjuti dengan melakukan revisi terhadap desain awal modul. Setelah validasi dari kedua validator bahan ajar Bahasa Arab berbasis pendekatan komunikatif dilakukan perbaikan desain awal sesuai hasil dari validasi ahli. Adapun grafik perbandingan nilai validator 1 dan 2 adalah sebagai berikut:

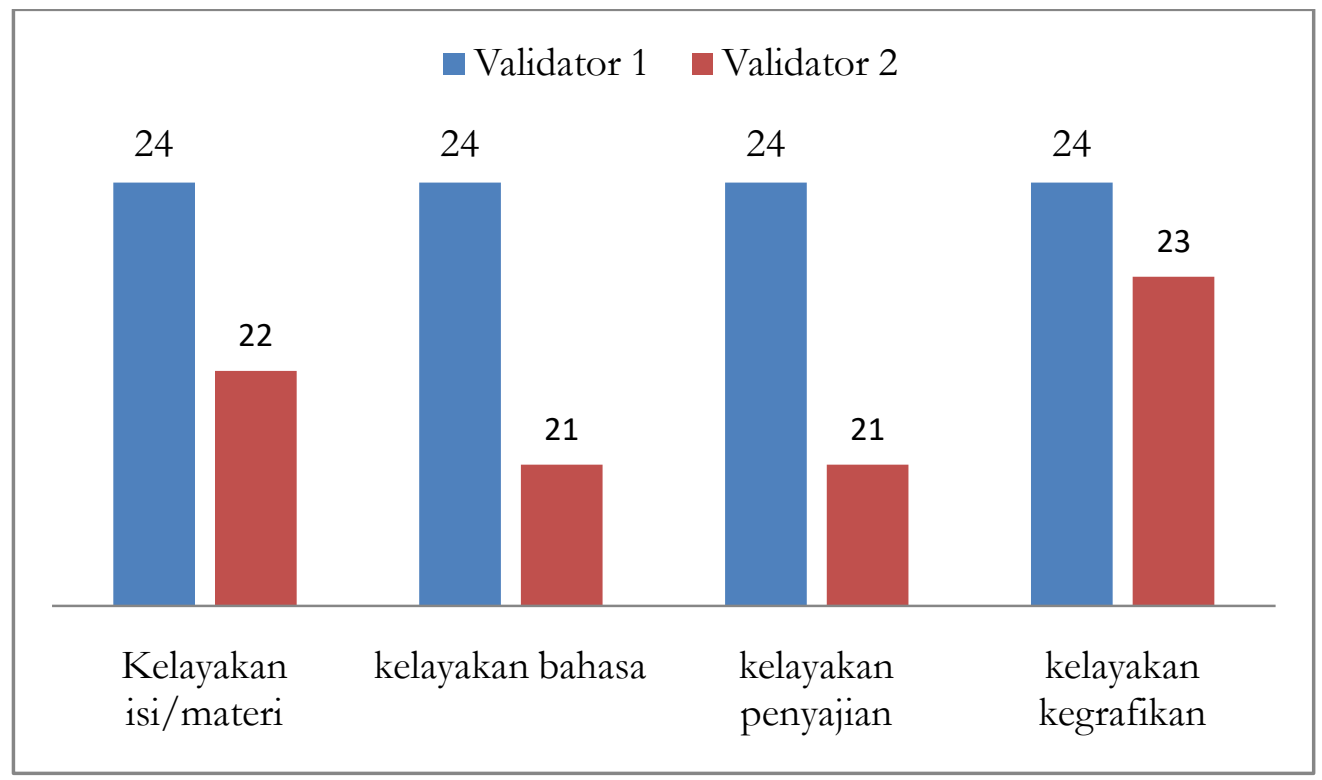

Grafik 5

Perbandingan Hasil Penilaian Validator 1 dan Validator 2 terhadap Bahan Ajar Berbentuk Modul Bahasa Arab Berbasis Pendekatan Komunikatif

Berikut grafik perbandingan hasil validasi ahli isi/materi, ahli penyajian, ahli bahasa, dan ahli kegrafikaan terhadap bahan ajar Bahasa Arab berbasis pendekatan komunikatif.

\begin{tabular}{|r|cccc|}
\hline 24 & & & 23,5 \\
23,5 & 23 & 22,5 & 22,5 & \\
23 & & & & \\
22,5 & & Kelayakan & kelayakan & kelayakan \\
22 & & bahasa & penyajian & kegrafikan \\
\cline { 2 - 4 } & Kelayakan & & & \\
\hline
\end{tabular}

Grafik 6

Perbandingan Hasil Penilaian Kelayakan terhadap Bahan Ajar Berbentuk Modul Bahasa Arab Berbasis Pendekatan Komunikatif 


\section{Penutup}

Berdasarkan hasil penelitian dan pembahasan yang dipaparkan sebelumnya, maka disimpulkan bahwa bahan ajar Bahasa Arab yang digunakan selama ini belum disusun sesuai dengan kebutuhan siswa dan belum secara maksimal meningkatkan kemampuan berbicara Bahasa Arab siswa. Pengembangan bahan ajar Bahasa Arab disusun berdasarkan hasil perencanaan dan desain pengembangan dengan tiga tema yaitu al-Bayanaats asy-Syakbshiyyah, al-Hayah fi al-Usrah, dan al-Murafiq al-'Ammah fi al-Madrasah. Modul Bahasa Arab berbasis pendekatan komunikatif ini berjumlah 28 halaman. Rata-rata nilai dari validator terhadap desain awal modul bahan ajar Bahasa Arab berbasis pendekatan komunikatif untuk siswa MA Muhammadiyah yaitu 22,87 dengan kategori sangat baik. Berdasarkan kesimpulan yang telah dikemukan, maka saran yang dapat diberikan adalah bagi pengajar Bahasa Arab diharapkan untuk bisa mengembangkan bahan ajar sendiri sesuai dengan kebutuhan sehingga bahan ajar tersebut memiliki kesesuaian dengan kurikulum yang ada, kemudian hendaknya mengimplemetasikan bahan ajar Bahasa Arab yang telah dikembangkan tersebut sehingga diketahui efektivitas untuk terus dikembangkan secara kontinu. 


\section{Bibliografi}

Arifa, Zakiyah, dan Dewi Chamidah. "Pengembangan Bahan Ajar Qawaid Bahasa Arab Berbasis Mind Map Untuk Tingkat Perguruan Tinggi." ElQudwah: Jurnal Penelitian Integrasi Sains Dan Islam 4 (2011). http://ejournal.uin-malang.ac.id/index.php/lemlit/article/view/1947.

Daryanto, Daryanto. Menyusun Modul (Bahan Ajar Untuk Persiapan Guru Dalam Mengajar. Yogyakarta: Gava Media, 2013.

Edi, Relit Nur. "Pendekatan Komunikatif (Al Madkhol Al-Ittisholi) Dalam Pembelajaran Bahasa Arab.” Jurnal Al Bayan UIN Raden Intan 4, no. 2 (2012). https://www.neliti.com/publications/74272/pendekatankomunikatif-al-madkhol-al-ittisholi-dalam-pembelajaran-bahasa-arab.

Muradi, Ahmad. "Pendekatan Komunikatif Dalam Pembelajaran Bahasa Arab." Arabiyat: Jurnal Pendidikan Bahasa Arab Dan Kebahasaaraban 1, no. 1 (1 Juli 2014): 29-48. https://doi.org/10.15408/a.v1i1.1129.

Nurlaila, Nurlaila. "Pengembangan Bahan Ajar Bahasa Arab Berbasis Komunikatif Untuk Mahasiswa Program Studi Keperawatan Stikes Purna Bhakti Husada Batusangkar." Ta'dib 14, no. 2 (28 September 2016). https://doi.org/10.31958/jt.v14i2.206.

Prastowo, Andi. Panduan Kreatif Membuat Bahan Ajar Inovatif. Yogyakarta: Diva Press, 2012.

Setiadi, Alif Cahya. "Pengajaran Bahasa Dengan Pendekatan Komunikatif: Analisis Atas Teori Transformatif-Generatif Noam Chomsky." AtTa'dib 4, no. 1 (27 Agustus 2016). https://doi.org/10.21111/attadib.v4i1.569.

Setyowati. Metode Penelitian Pendidikan dan Pengembangan. Jakarta: Kencana, 2010.

Sugiyono. "Metode Penelitian Kuantitatif Kualitatif dan R\&D." Bandung: Alfabeta, 2012.

Sukiminiandari, Yunieka Putri, Agus Setyo Budi, dan Yetti Supriyati. "Pengembangan modul pembelajaran fisika denganpendekatan saintifik." Prosiding seminar nasional fisika (e-journal) 4 (30 Oktober 2015): SNF2015-II-161-64.

Zaid, Abdul Hafidz. "Pendekatan Komunikatif Dalam Pengajaran Bahasa Arab

(Pengalaman Pondok Modern Darussalam Gontor)." At-Ta'dib 7, no. 2 (12 Desember 2012). https://doi.org/10.21111/at-tadib.v7i2.77.

Zulhanan, Zulhanan. "Model Pembelajaran Bahasa Arab Komunikatif." Jurnal Al Bayan UIN Raden Intan 6, no. 2 (2014). https://www.neliti.com/publications/73690/model-pembelajaranbahasa-arab-komunikatif. 